\title{
THE EVOLUTION OF THE ASTIN MEMBERSHIP
}

A large majority of ASTIN members never attend ASTIN Colloquia. Hence they do not have the occasion to listen to the Chairman's, Treasurer's and Secretary's reports at the General Assemblies. Their only contact with the ASTIN Committee is this Bulletin. Therefore, it seems appropriate to convey, from time to time, important news concerning our Association in the pages of the ASTIN BULLETIN.

As stated by article 2 of our rules, the objective of ASTIN is the promotion of actuarial research, particularly in non-life insurance. To this end, the Association organizes the ASTIN Colloquia and publishes the ASTIN BULLETIN. Promotion of research includes its dissemination to the largest possible audience. So the ASTIN Committee considers the increase of the membership as one of its most important goals.

The recent news concerning the evolution of the number of members is particularly good, as Figure 1 shows. Since its foundation in 1957, ASTIN progressively built up its membership until 1976, when an all-time high of 1279 was recorded. The subsequent years were, however, disquieting, as our size decreased, then stagnated, dropping to 1127 in 1981. Fortunately, since 1983, we are experiencing an unprecedented growth: a $47 \%$ increase in less than 5 years leads to a current membership of 1755 .

In addition, the ASTIN BULLETIN is available by subscription to libraries, nonactuaries and students. The number of such external subscriptions has been slowly increasing over the years, attaining 130 nowadays. This modest figure nevertheless adds to the circulation of the Bulletin: this issue is currently in the

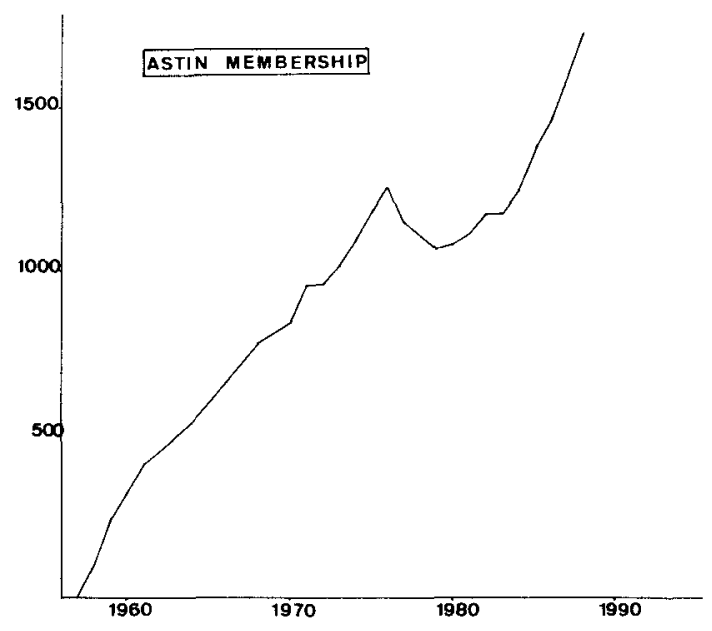

FIGURE 1. ASTIN membership since 1957. 
TABLE 1

ASTIN MENBERSHIP IN 1981 AND 1988

\begin{tabular}{|c|c|c|}
\hline Country & 1981 & 1988 \\
\hline Argentina & 3 & 5 \\
\hline Australia & 78 & 68 \\
\hline Austria & 9 & 11 \\
\hline Bahamas & 1 & 0 \\
\hline Belgium & 34 & 50 \\
\hline Bermuda & 2 & 0 \\
\hline Brazil & 2 & 1 \\
\hline Canada & 45 & 65 \\
\hline Chile & 0 & 1 \\
\hline Costa Rica & 2 & 1 \\
\hline Denmark & 32 & 52 \\
\hline Egypt & 1 & 3 \\
\hline EI Salvador & 2 & 2 \\
\hline Finland & 40 & 59 \\
\hline France & 60 & 114 \\
\hline Germany & 28 & 40 \\
\hline Great Britain & 92 & 109 \\
\hline Greece & 1 & 5 \\
\hline Honduras & 0 & 4 \\
\hline Hong Kong & 0 & 1 \\
\hline Iceland & 8 & 7 \\
\hline Ireland & 2 & 2 \\
\hline Israel & 18 & 23 \\
\hline Italy & 38 & 57 \\
\hline Jamaica & 1 & 1 \\
\hline Japan & 43 & 71 \\
\hline Kenya & 0 & 1 \\
\hline Kuwait & 0 & 1 \\
\hline Luxemburg & 1 & 1 \\
\hline Mexico & 23 & 26 \\
\hline Netherlands & 87 & 121 \\
\hline New Zealand & 11 & 9 \\
\hline Norway & 28 & 48 \\
\hline Panama & 1 & 7 \\
\hline Poland & 2 & 2 \\
\hline Portugal & 11 & 11 \\
\hline South Africa & 12 & 22 \\
\hline Spain & 25 & 42 \\
\hline Sri Lanka & 1 & 1 \\
\hline Sweden & 37 & 51 \\
\hline Switzerland & 42 & 55 \\
\hline Taiwan & 0 & 2 \\
\hline Trinidad \& Tobago & 3 & 0 \\
\hline United Arab Emirates & 0 & 1 \\
\hline United States & 283 & 583 \\
\hline Venezuela & 18 & 13 \\
\hline Yugoslavia & 0 & 5 \\
\hline Zimbabwe & 0 & 1 \\
\hline TOTAL & 1127 & 1755 \\
\hline
\end{tabular}


hands of no less than 1879 readers. We expect to reach the 2000 mark early in 1989.

The most favourable aspect of this steady growth is of course the increased circulation of new actuarial ideas. Other consequences are not to be neglected:

- the marginal printing costs of any mathematical journal are of course a decreasing function of its circulation, due to the high type-setting costs. So the longer the membership increase continues, the longer we can maintain our dues at their present low level. The last time the dues were increased was July 1977 !

- Authors have a strong incentive to submit their papers to the ASTIN BULLETIN knowing that it has a circulation which is much, much larger than all other non-life actuarial journals.

Table 1 presents the breakdown by country of our membership, in 1981 and in April 1988.

JEAN LEMAIRE

ASTIN Chairman 